\title{
反応性骨材を用いた供試体の表面保護工による膨張抑制効果 †
}

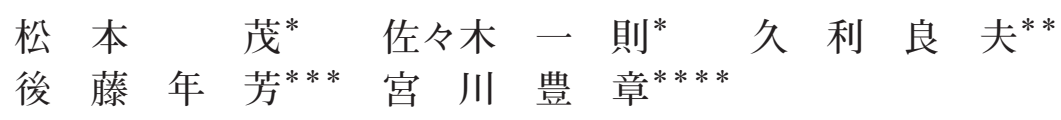

\section{Control of Alkali-Silica Expansion by Various Surface Systems}

\author{
by
}

\author{
Shigeru Matsumoto *, Kazunori SASAKI ${ }^{*}$, Yoshio Hisari ${ }^{* *}$, \\ Toshiyoshi Gото ${ }^{* * *}$ and Toyoaki Mryagawa ${ }^{* * * *}$
}

\begin{abstract}
This paper presents the results of long term outdoor exposure of specimens made of reactive aggregate and ASR expansion control by various surface penetrant methods, surface coating methods and injection methods. All methods have been able to control the ASR expansion of specimens. Especially, silane penetrant method can control the ASR expansion even if the surface layer removed. And this paper deals with the basic investigations on the amount of impregnated silane in addition to the impregnation depth by applying differential thermal analysis (TG-DTA) of samples obtained from different depths in concrete. A good linear relation between the exothermic peak area of the heat flow curve and the content of silane was confirmed.
\end{abstract}

Key words : Silane, Alkali silica reaction, Differential thermal analysis, Reactive aggregate

\section{1 緒言}

我が国に打けるアルカリ骨材反応に関する研究は, 1980 年代に阪神高速道路の橋脚で発見された大きなひび 割れの原因であることが確認されたことを一つの契機と して広範に行われてきた。笛の結果，コンクリート配合 や維持管理の分野を中心として各種の対策が実施されて きた。研究の初期においては，アルカリ骨材反応による 劣化が生じても部材や構造物の安全性が問題になること はほとんどなかった。しかし，土木学会が 2001 年に制 定したコンクリート標準示方書 [維持管理編 $]^{1}$ において 「鋼材の降伏や破断が発生し，部材として耐荷力に影響 を及ぼす」場合があることが示され，時を同じくして鉄 筋の破断事例が報告されるようになった。骨材の反応性 の有無やアルカリ総量などに関する対策がとられたこと により新設構造物がアルカリ骨材反応によって性能上の 問題を生じる可能性は著しく減少している。しかし，こ れらの規制が行われる以前に建設された構造物，なかで も，既にアルカリ骨材反応による劣化を生じている構造 物については, 維持管理上, 特段の配慮が必要である。

本研究では, アルカリ骨材反応を生じた構造物への対 策として広く利用されている各種の表面保護工の膨張抑 制効果について, 供試体を用いた長期にわたる屋外暴露 結果から評価するとともに, シラン系表面含浸材の含浸 深さ測定について差動型示差熱天秤を用いた示差熱分析 (DAT) の適用性評価を行った。

\section{2 実 験 概 要}

実験は 2 種類に大別される。第 1 の実験は反応性骨材 を使用した供試体の長期間にわたる屋外暴露実験であり， 各種表面保護工の膨張抑制効果を評価することを目的と したものである．第 2 の実験は，実験 1 で作成した供試 体から採取した試料打よび微粉末化したセメントペース トとシラン系表面含浸材を混合した試料を用いた示差熱 分析と, 実験 1 で作成した供試体から作成したコア供試 体の暴露試験であり, シラン系表面含浸材の含浸深さと 膨張抑制効果の評価を目的としたものである.

\section{$2 \cdot 1$ 実験 1 （長期暴露実験）}

供試体の配合を Table 1 に示す。応性骨材として粗 骨材に古銅輝石安山岩を用いるとともに, 膨張率が $2,000 \sim 3,000 \mu$ となるよう $\mathrm{NaCl}$ を添加して総アルカリ 量を $9 \mathrm{~kg} / \mathrm{m}^{3}$ とした。供試体寸法は $100 \times 100 \times 400 \mathrm{~mm}$ とし, 成型後 28 日までは $40^{\circ} \mathrm{C}$, R. H. $100 \%$ の環境で促進 養生した後, Table 2 に示す表面保護工を各メーカーの仕 様に従って施工した。 その後, 1 週間気乾養生し, 805 週 間（約 15 年半）の屋外暴露に供した。暴露場所は大阪

Table 1 Mix proportion.

\begin{tabular}{|c|c|c|c|c|}
\hline Max. size $(\mathrm{mm})$ & Slump $(\mathrm{cm})$ & W/C $(\%)$ & Air Content $(\%)$ & Sand ratio(\%) \\
\hline 20 & 8 & 50 & 3 & 46 \\
\hline \multicolumn{5}{|c|}{ Unit weight $\left(\mathrm{kg} / \mathrm{m}^{3}\right)$} \\
\hline Water & Cement & Sand & Gravel & Admixture \\
\hline 169 & 338 & 823 & 949 & $845 \mathrm{ml}$ \\
\hline
\end{tabular}

\footnotetext{
$\dagger$ 原稿受理 平成 20 年 2 月 18 日 Received Feb. 18, 2008 @ 2008 The Society of Materials Science, Japan

* 正 会 員 阪神高速道路株) ₹541-0056 大阪市中央区久太郎町, Hanshin Expressway Co. Ltd., Chuo-ku, Osaka, 541-0056

** 阪神高速道路㑣) $\overline{7}$ 541-0056 大阪市中央区久太郎町, Hanshin Expressway Co. Ltd., Chuo-ku, Osaka, 541-0056

*** 正会員 (株中研コンサルタント ₹551-0021 大阪市大正区南恩加島, Chuken Consultant Co. Ltd., Taisyo-ku, Osaka, 551-0021

**** 正会員 京都大学大学院工学研究科 ₹615-8520 京都市西京区京都大学桂, Dept. of Civil and Earth Resources Eng., Nishikyo-ku, Kyoto, $615-8520$
} 
Table 2 Treatment materials.

\begin{tabular}{|c|c|c|c|c|c|c|c|c|c|c|}
\hline & \multicolumn{2}{|c|}{$\mathrm{A}: \mathrm{PCM}$} & \multicolumn{2}{|c|}{$\begin{array}{c}\text { B : Urethane } \\
\text { (Polybutadiene) }\end{array}$} & \multicolumn{2}{|c|}{$\begin{aligned} \text { C: } & \text { Modified Silicone } \\
& + \text { PCM (acrylic) }\end{aligned}$} & \multicolumn{2}{|c|}{$\begin{array}{c}\text { D } \\
\text { Epoxy resin }\end{array}$} & \multicolumn{2}{|c|}{$\begin{array}{c}\mathrm{E} \\
\text { Silane }+ \text { Epoxy resin }\end{array}$} \\
\hline & Material & Quantity & Material & Quantity & Material & Quantity & Material & Quantity & Material & Quantity \\
\hline Primer & PCM & 0.16 & Urethane & 0.17 & & & Epoxy resin & 0.10 & & \multirow{2}{*}{0.10} \\
\hline Putty & PCM & 0.41 & Urethane & 0.29 & & & Epoxy resin & 0.30 & & \\
\hline Bottom Coat & & & & & & & & & Epoxy resin & \multirow{2}{*}{0.34} \\
\hline Middle Coat & $\mathrm{PCM}$ & 0.61 & Urethane & $0.25 \times 2$ & Epoxy resin hybrid & $0.40+0.20$ & Epoxy resin & $0.35 \times 3$ & Silane & \\
\hline \multirow[t]{3}{*}{ Top Coat } & PCM & 0.31 & Acrylic urethane & 0.18 & PCM+Silane & $1.00+0.15$ & Polyurethane & 0.13 & Polybutadiene & 0.10 \\
\hline & \multicolumn{2}{|c|}{$\begin{array}{c}\text { F: Urethane } \\
\text { (Polybutadiene) }\end{array}$} & \multicolumn{2}{|c|}{$\begin{array}{c}\mathrm{G} \\
\text { Silane + PCM }\end{array}$} & \multicolumn{2}{|c|}{$\begin{array}{l}\mathrm{H}: \mathrm{PCM} \text { (*injection) } \\
\text { (alkali ion adsorbring) }\end{array}$} & \multicolumn{2}{|c|}{$\begin{array}{c}1: \text { Lithium nitrate } \\
(*: \text { injection })+\text { Silane }\end{array}$} & \multicolumn{2}{|c|}{$\begin{array}{c}\text { J } \\
\text { Silane + PCM }\end{array}$} \\
\hline & Material & Ouantity & Material & Ouantity & Material & Quantity & Material & Ouantity & Material & Ouantity \\
\hline Primer & Epoxy resin & 0.15 & & & & & & & & \\
\hline Putty & Urethane & 0.30 & & & & & & & & \\
\hline Bottom Coat & & & Silane & $0.12 \times 2$ & PCM & $0.10^{*}$ & Lithium nitrate & $0.23 *+0.09$ & Silane & 0.20 \\
\hline Middle Coat & Urethane & 1.20 & PCM & $0.70 \times 3$ & & & $\mathrm{PCM}$ & 0.20 & $\begin{array}{c}\text { Flexible polymer- } \\
\text { modified cement mortum }\end{array}$ & $1.20+1.10$ \\
\hline Top Coat & Acrylic urethane & 0.12 & Acrylic emulsions & $0.10 \times 2$ & Silane & 0.10 & Silane & 0.15 & Acrylic latex & $0.10 \times 2$ \\
\hline
\end{tabular}

市大正区南恩加島に位置する 2 階建ビルの屋上で，海浜 には近いが内湾であることから飛来塩分はほとんど無い と考えられる。

なお，H（アルカリ金属イオン吸着）と, I（亜硝酸リ チウム + シラン) は, 表面保護工と併せて注入孔からの 注入を行っている。この 2 種類を除く他の 8 種類の表面 保護工は暴露開始 (平成 4 年) 当時の「コンクリート構 造物の表面保護工便覧 (案) ・同解説」(阪神高速道路公 団・日本材料学会) ${ }^{2)}$ の F 種（アルカリ骨材反応用の表面 保護工）に適合した表面保護工である。供試体は各 3 体 で実験を開始し，284 週（約 5 年半）経過時点で各 1 体 についてディスクサンダーによりプライマー・パテまで 研削し，屋外暴露を継続した。

測定項目は長辺方向の長さおよび質量とし，JCI AAR3 「コンクリートのアルカリシリカ反応性試験方法 (案)」 ((社)日本コンクリート工学協会) に準じて測定した.

\section{$2 \cdot 2$ 実験 2 (示差熱分析とコア膨張試験)}

予備試験として実施した示差熱分析結果を Fig. 1 に示 す。試料はシラン系表面含浸材を塗布したコンクリート テストピース表面から採取した。 シランを塗布しないコ ンクリートテストピースから採取した試料では現れない $350^{\circ} \mathrm{C}$ 付近を中心とした発熱ピークが認められた。

示差熱分析の試料は実験 1 で作成した供試体から採取 したものと，実験 2 の微粉末化したセメントペーストと シラン系表面含浸材を混合したものとに大別される。前 者は，通常の施工でどの程度シランが含浸しているかの 評価を目的としたもので，G（シラン + PCM）を施工し

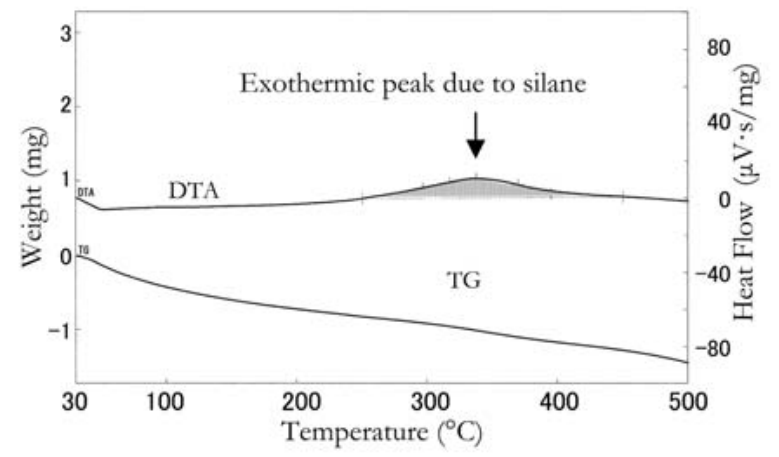

Fig. 1 Result of TG-DTA of sample containing silane.

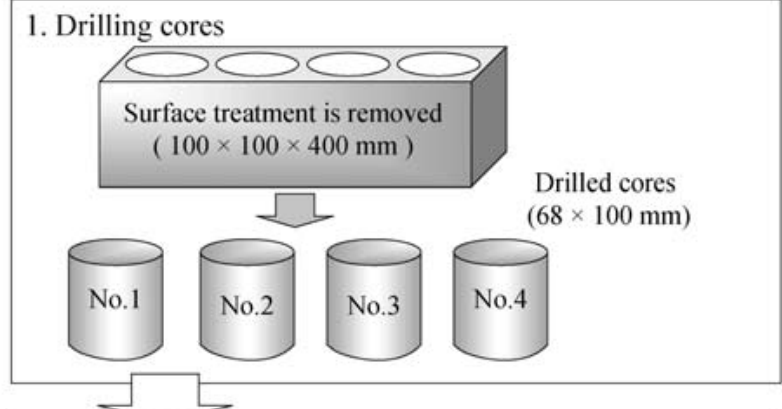

2. Grinding surface, sampling and differential thermal analysis of the samples

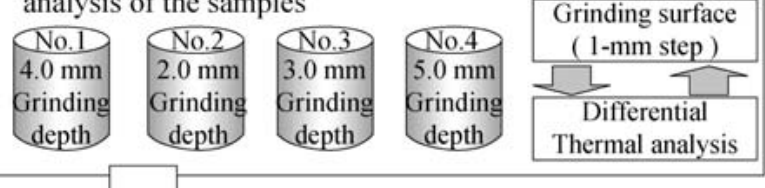

3. Sealing side surface of the core specimen and Outdoor exposure

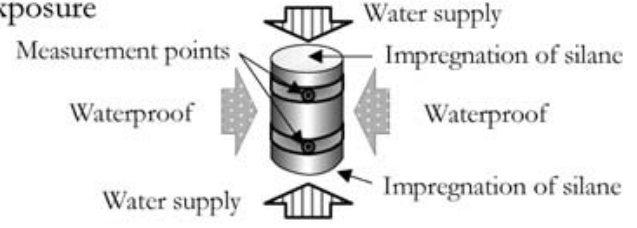

Fig. 2 Flow of experiment and DTA.

た長期暴露試験供試体のうち 284 週で表面保護工を研削 した供試体からコアを作成し，このコアの表面から採取 した．Fig．２にその手順を示す．表面からの深さと含浸 量の関係を評価するため，試料はコアの表面から研磨機 で $1.0 \mathrm{~mm}$ ずつ研削しながら Table 3 に示す深さで両面 （上下面）から各々 1 サンプルずつ採取した。採取にあ たっては，主に骨材以外の部分をピックで掻き取り，粗 い砂粒子は除いた後に乳鉢で微粉末化した。示差熱分析

Table 3 Samples for deferential thermal analysis.

\begin{tabular}{|c|c|c|c|c|c|c|}
\hline \multirow{2}{*}{$\begin{array}{c}\text { Core } \\
\text { No. }\end{array}$} & \multicolumn{4}{|c|}{ Sampling depth (mm) } & $\begin{array}{c}\text { Total } \\
\text { depth (mm) }\end{array}$ & $\begin{array}{c}\text { Number of } \\
\text { sample }\end{array}$ \\
\hline 1 & 2 & 3 & 4 & 5 & 4 & 6 \\
\hline 2 & $\bigcirc$ & & & & 4 & 2 \\
\hline 3 & $\bigcirc$ & $\bigcirc$ & & & 3 & 4 \\
\hline 4 & $\bigcirc$ & $\bigcirc$ & $\bigcirc$ & $\bigcirc$ & 5 & 8 \\
\hline
\end{tabular}




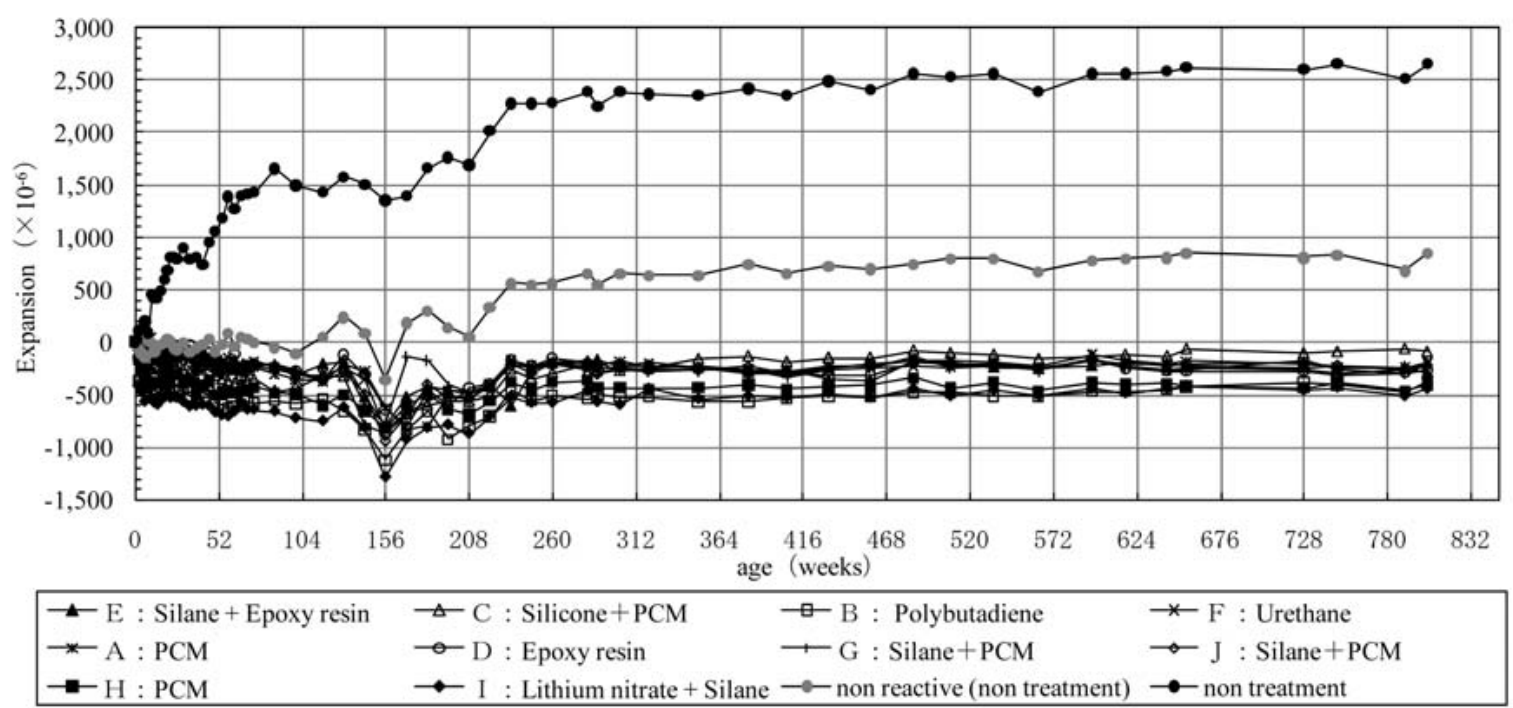

Fig. 3 Expansion of specimens.

の試料計量量は $30 \mathrm{mg}$ ，昇温速度は $10^{\circ} \mathrm{C} /$ 分とした。さ らに，シランの含浸量と膨張抑制効果との関係を評価す るため, 研削後のコア供試体を再度屋外暴露し，膨張率 を測定した (Fig. 2)，測定に当たってはコア中央部の約 $50 \mathrm{~mm}$ はコンタクトゲージで，コア全長は八イトゲージ で測定した。

次に微粉末化したセメントペーストとシラン系表面含 浸材を混合した試料について示差熱分析を行った。これ はシラン系表面含浸材の含有量が既知の試料を示差熱分 析することにより，含浸の程度を定量的に評価すること を目的としたものである。試料は， $\phi 100 \times 200 \mathrm{~mm}, \mathrm{w} / \mathrm{c}=$ $50 \%$ のメントペースト供試体を作成し，24 時間後に脱 型，養生（6 日間の水中養生 $20^{\circ} \mathrm{C} ， 21$ 日間の気中養生 $20^{\circ} \mathrm{C} \cdot$ R.H. $\left.60 \%\right)$ 後に $20 \mathrm{~mm}$ 厚にスライス, 粉砕したも のを, シラン系表面含浸材と混合し, $60^{\circ} \mathrm{C}$ で乾燥, 微粉 末化して作成した。

\section{3 実験結果および考察}

\section{$3 \cdot 1$ 実験 1 （長期暴露実験）}

Fig. 3 に長さ変化率を示す。表面保護工を施工してい ない供試体が約 5 年 (260 週) で $2,300 \mu$ 程度の膨張に達 し, 収束期に達しているのに対し, 表面保護工を施工し たものはいずれも収縮している。別途測定した質量につい ても, 減少の度合いは徐々に小さくなっているものの長期 的には依然として減少傾向が持続している。したがって， いずれの表面保護工も長期にわたって吸水防止性能や内 部からの水蒸気透過性能が維持され，膨張抑制効果が維 持されていると考えられる。骨材の反応性についてどの ような方法で確認したかの詳細は不明であるが，非反応 性骨材を用いた供試体も $800 \mu$ 程度の膨張が生じており， ある程度の反応性を有していた可能性が高い.

284 週経過時点でディスクサンダーを用いて表面保護 工をプライマー・パテまで研削し，屋外暴露を継続した 供試体の長さ変化率を Fig. 4 に示す。ほとんどの供試体 で塗膜の除去直後から急激な膨張が観察されたが，G (シラン + PCM ) と I（亜硝酸リチウム + シラン）につい

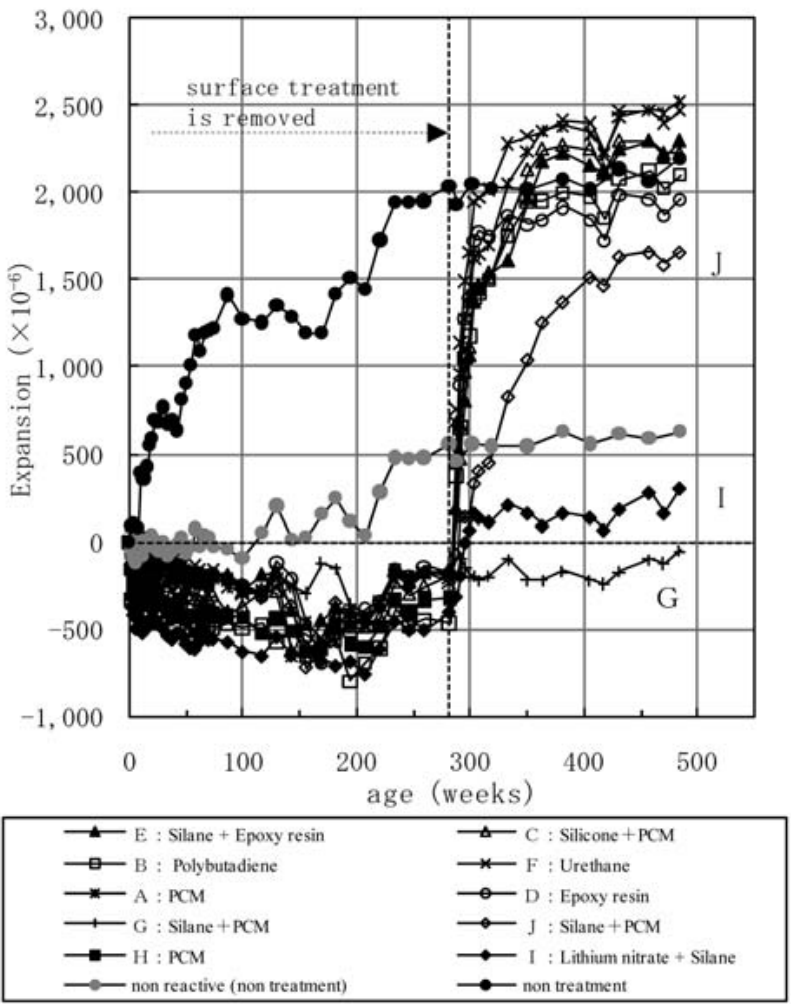

Fig. 4 Expansion of specimens. (surface treatment is removed)

ては若干膨張しているものの，実用上問題とならないレ ベルに膨張が抑制された。また，J（シラン＋PCM）は， $\mathrm{G}$ と類似した材料であり, 膨張速度は他と比べて遅いも のの最終的には $1,600 \mu$ 程度まで膨張した。

以上の結果より，表面保護工の適用によりコンクリー トへの水分供給が遮断され，屋外暴露環境下でも 15 年以 上にわたって膨張を抑制することができることがわかる. また，表面被覆工を除去しても，G（シラン＋PCM）お よびI（亜硝酸リチウム + シラン）については，表面含 浸工の効果により引き続き膨張抑制に必要な吸水防止性 能や内部からの水蒸気透過性能が維持されていると考え 
られる。類似した材料である Gと J（シラン+ PCM）で 膨張抑制効果に差が生じた理由については後述する。な お，内部に注入された亜硝酸リチウムによる効果は明確 でない。

\section{$3 \cdot 2$ 実験 2 (コア供試体の示差熱分析と膨張試験)}

実験 2 における試料の採取深さと発熱ピーク面積との 関係を Fig. 5 に示す. 採取深さが深くなるほど発熱ピー ク面積が小さくなる，すなわち，供試体表面から深くな るほどシランの含浸量が減少する傾向が確認された。ま た, 採取深さが $5.0 \mathrm{~mm}$ であっても少量のシランが含浸し ている。なお，図中の破線は，Fig. 2 に示すコア採取後 の供試体 $(100 \times 100 \times 400 \mathrm{~mm})$ の異なる深さから採取し た試料の分析結果である。一方，G と類似した表面保護 工である J（シラン + PCM）についての示差熱分析結果 を $\mathrm{G}$ と比較すると, 同じ深さであっても発熱ピーク面積 が小さい，すなわち，シラン含浸量が少ないことがわか る。このため, 表面保護工はく離後の膨張抑制効果に差 が生じたものと考えられる。

コア供試体を屋外暴露した際の長さ変化率測定結果を Fig. 6 (コンタクトゲージ法), Fig. 7 (ハイトゲージ法) に示す. Fig. 6 より, コアNo. 1，3，4 は膨張し，コア No. 2 はほとんど膨張していない. これより, 屋外暴露 の環境下では，コンクリート表面から $2.0 \mathrm{~mm}$ の深さまで 膨張抑止効果が期待できる程度のシランが含浸している と考えられる. Fig. 5 との関連から, 今回の膨張試験で

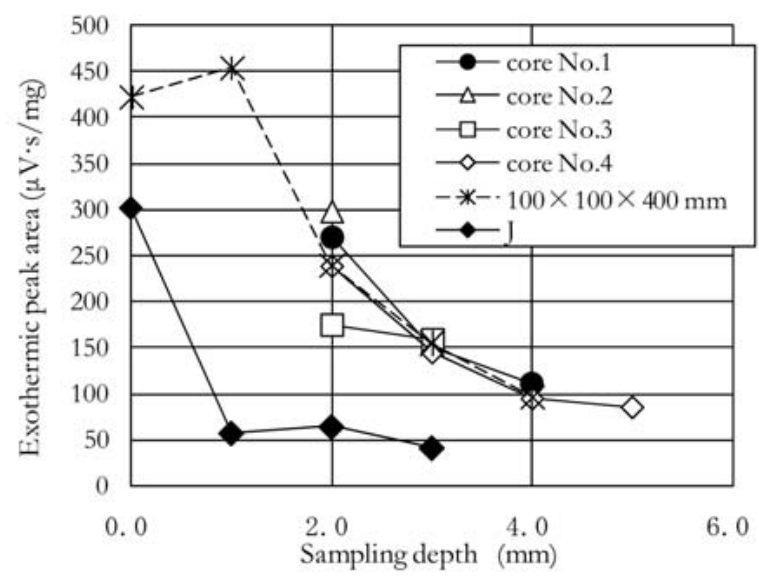

Fig. 5 Relationship between sampling depth and exothermic peak area.

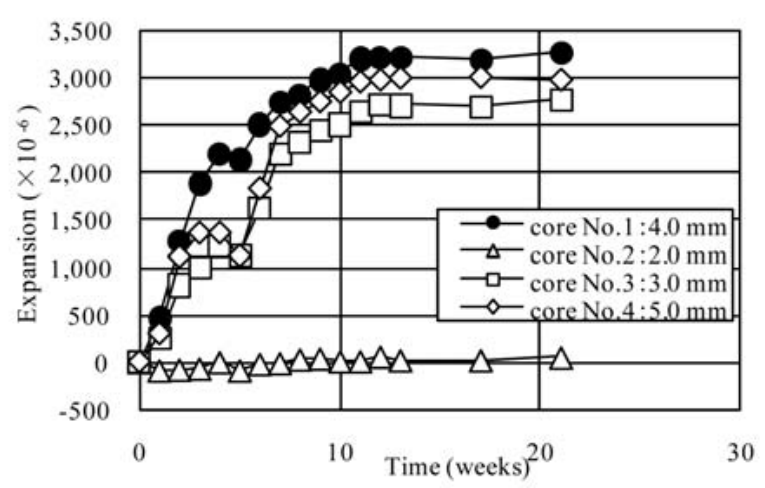

Fig. 6 Expansion of cores (contact gauge method).

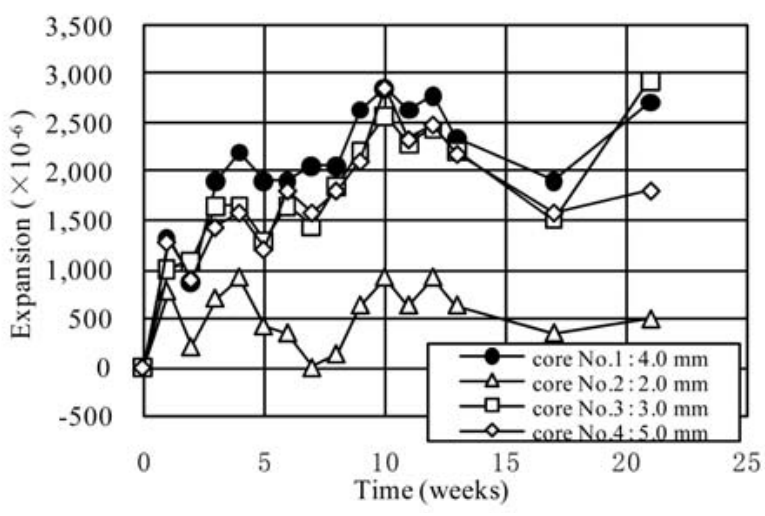

Fig. 7 Expansion of cores (height gauge method).

はシランの発熱ピーク面積が $300 \mu \mathrm{V} \cdot \mathrm{s} / \mathrm{mg}$ 程度以上で 膨張抑制効果があり，発熱ピーク面積が $160 \mu \mathrm{V} \cdot \mathrm{s} / \mathrm{mg}$ 以下で膨張抑制効果がないと言える.

次に，コンタクトゲージ法による膨張率とハイトゲー ジ法による膨張率を比較する。研磨深さ $2.0 \mathrm{~mm}$ の No. 2 コアに扎てて ポイント間の膨張率を測定するコンタク トゲージ法で測定した場合はほとんど膨張していないが， コア全長の膨張率を測定するハイトゲージ法で測定した 場合はやや膨張している。この結果から，コアNo.2の 内部はほとんど膨張せず，表層部のみが膨張したと考え られる。したがって，シラン系表面含浸材の吸水防止機 能によりコア表層部で水の浸透が抑えられ，コア内部に は膨張を生じるほどの水が浸透しなかったと推測できる.

研磨深さ $3.0 \mathrm{~mm}$ 以上のコア No. 1，3，4 において， コンタクトゲージ法では膨張率が単調増加の傾向にある ことから, 晴天時の乾燥の影響をあまり受けずにコア内 部が膨張したと考えられる。一方，ハイトゲージ法では， 全体的には膨張傾向にあるものの, 前回測定值と比較し て収縮する場合がある。この原因として，晴天時の乾燥 の影響を受けコア表層部が収縮したことが考えられる. これより，コンクリート内部と表層部では，水分の供給 条件の違い等によりアルカリ骨材反応による膨張の挙動 が異なるものと考えられる。

\section{$3 \cdot 3$ 実験 2 (シラン含浸セメントペーストの示差熱 分析）}

粉末化したセメントペーストとシラン表面含浸材は, 質量比 $1: 0.2,1: 0.5,1: 1,1: 2$ の割合で混合したが, 質量比が $1: 1$ および $1: 2$ の試料については強制乾燥が 必要であった。そのため $60^{\circ} \mathrm{C}$ 乾燥機で 3 日間乾燥させ た. 質量比が $1: 1$ の試料についてはダマ状ではあるが乾 燥させることができたのに対し，質量比が $1: 2$ の試料に ついては依然として液体が残っていたため, 示差熱分析 を行わないこととし，その代わりに質量比が $1 ： 0.1$ の試 料を作製した。

各々の質量比のシラン含浸セメントペーストの示差熱 分析結果の例を, Fig. $8 \sim 11$ に示す. 質量比 $1: 0.1$ 抒 よび $1: 0.2$ の試料については $330^{\circ} \mathrm{C}$ 付近に発熱ピークが 1 つ生じた。一方, 質量比 $1 ： 0.5$ および $1 ： 1$ の試料に ついては発熱ピークが $2 つ\left(250^{\circ} \mathrm{C}\right.$ 付近と $\left.320 \sim 370^{\circ} \mathrm{C}\right)$ 


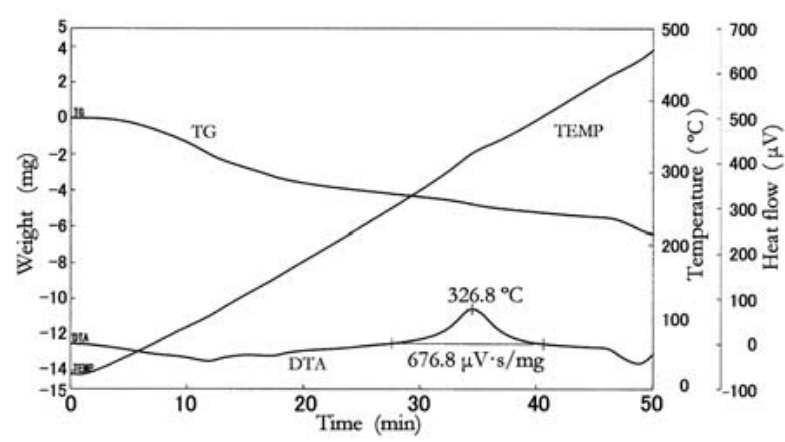

Fig. 8 Result of DTA $(1: 0.1)$.

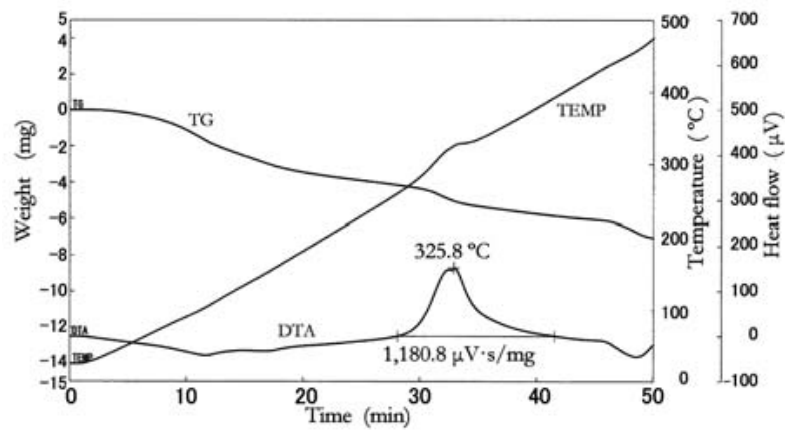

Fig. 9 Result of DTA (1:0.2)

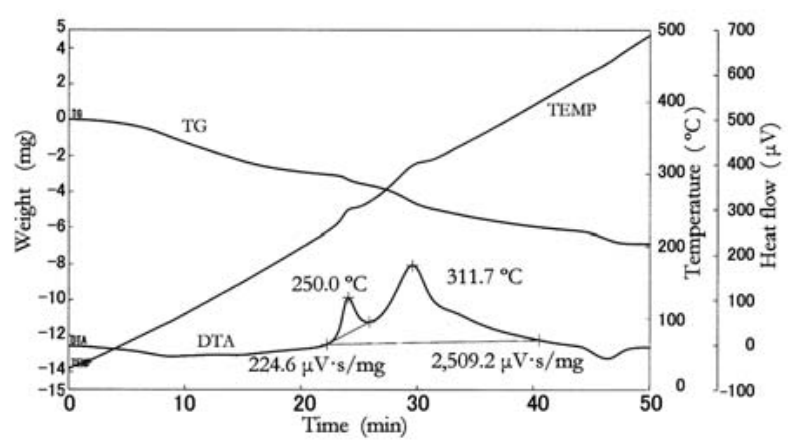

Fig. 10 Result of DTA (1:0.5).

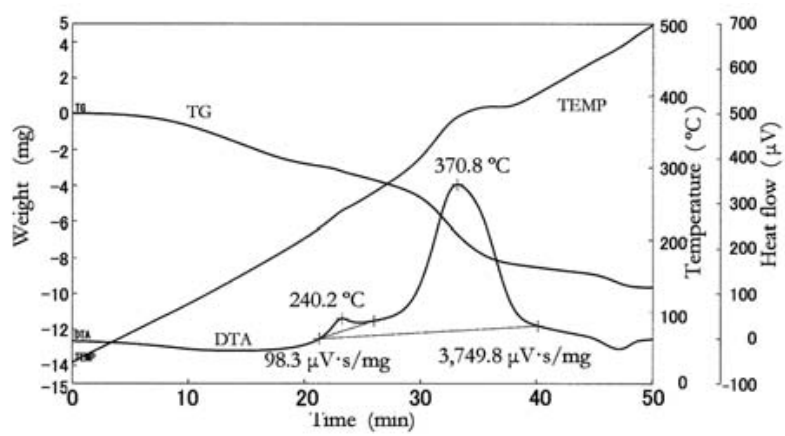

Fig. 11 Result of DTA $(1: 1)$.

生じた。質量比の高い試料において発熱ピークが 2 つ生 じた理由としては,これらの試料にはセメントと結合で きなかった余剩のシランが存在し，このためセメントと 結合していたシランの発熱ピーク $\left(320 \sim 370^{\circ} \mathrm{C}\right)$ と余 剩シランの発熱ピーク $\left(250^{\circ} \mathrm{C}\right)$ が現れた可能性が考えら れる。 そこで，シラン系表面含浸材単体の示差熱分析を
実施した。シラン系表面含浸材 $9.5 \mathrm{~g}$ を乾燥機で乾燥して アルコール類を揮散させ, 乾燥後の質量を $3.8 \mathrm{~g}$ まで濃縮 したものを示差熱分析したところ，Fig. 12 に示すように $240^{\circ} \mathrm{C}$ 付近に発熱ピークが生じた。これは, 質量比 $1: 0.5$ および $1: 1$ の試料の示差熱分析で生じた低温側の発熱 ピーク温度とほぼ一致する。このとき，発熱ピーク面積が 小さい一方で, 発熱ピークが現れる前に急激な質量低下 が生じている。これは試験中に白い煙のようなものの発生 が確認されたことからも, シラン系表面含浸材が燃焼す る前に蒸発した可能性が考えられる. シラン含浸セメント ペーストに佂いてシラン系表面含浸剤単体よりも発熱ピー

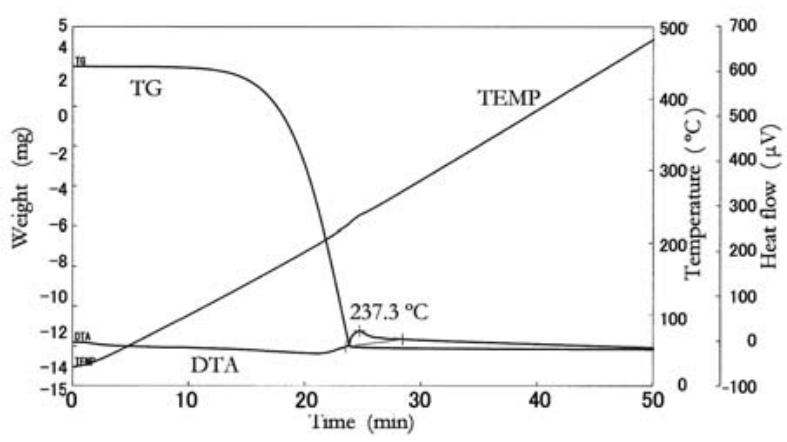

Fig. 12 Result of DTA (enriched silane).

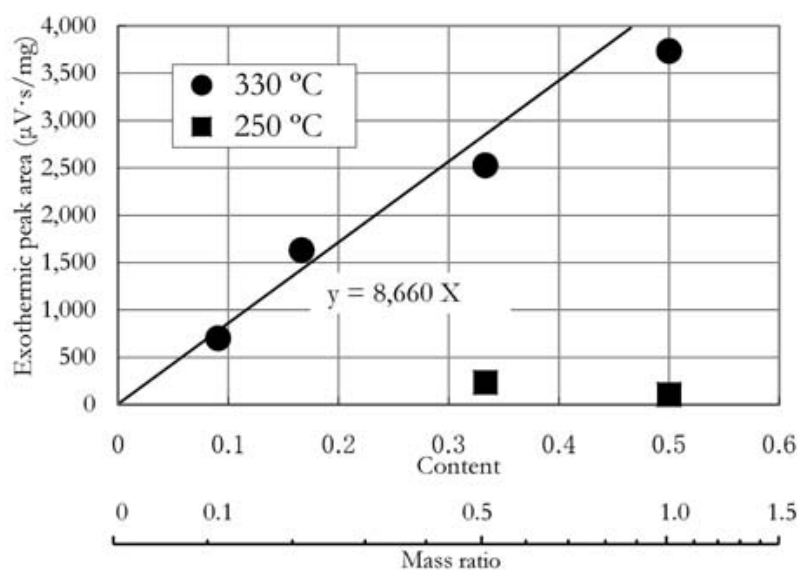

Fig. 13 Relationship between silane content and exothermic peak area.

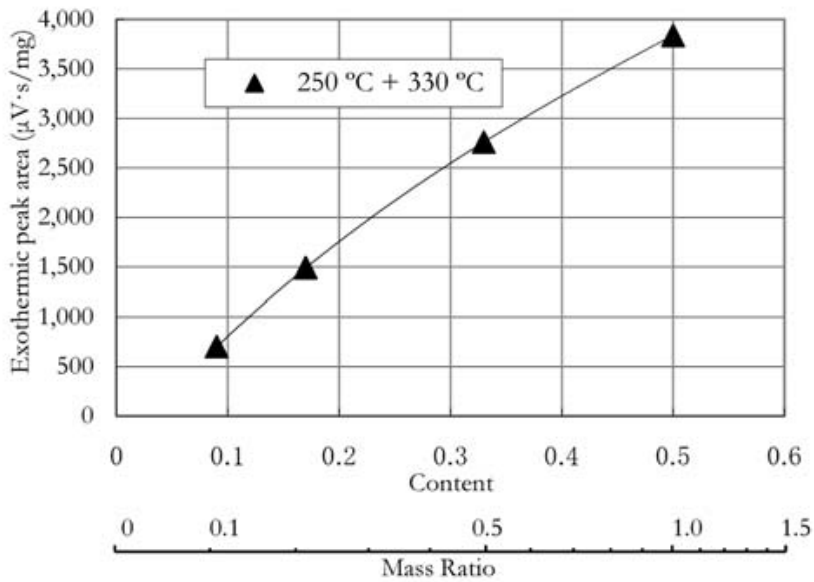

Fig. 14 Relationship between silane content and total exothermic peak area. 
ク温度が高い理由としては, シランとセメントが結合し ているためシラン単体よりも高い温度でなければシラン が分解しないことが可能性として考えられる。

示差熱分析から求めた発熱ピーク面積と質量比との関 係を Fig. 13，14 に示す. Fig. 13 より，シラン系表面含 浸材の質量比が高いほどシランの発熱ピークが大きくな り，両者は概ね比例関係にあることがわかる．原点と余 剩シランによると考えられる発熱ピークが生じない質量 比 $1: 0.1$ と $1: 0.2$ での結果から質量比 $\mathrm{x}$ と発熱ピーク

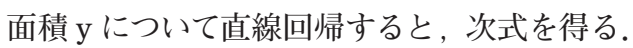

$$
\mathrm{y}=8,660 \mathrm{x}
$$

$\mathrm{y}:$ 発熱ピーク面積 $(\mu \mathrm{V} \cdot \mathrm{s} / \mathrm{mg})$,

$\mathrm{x}$ : 質量比

次に, Fig. 5 から得られた膨張抑制に必要な発熱ピー ク面積を $300 \mu \mathrm{V} \cdot \mathrm{s} / \mathrm{mg}$ 程度とした場合，上式を用いて これを質量比に換算すると，質量比は 0.0346 となる。ま た，膨張抑制に必要な発熱ピーク面積を $160 \mu \mathrm{V} ・ \mathrm{~s} / \mathrm{mg}$ 程度とした場合には，質量比は 0.0185 となる。

次に, 実験 1 から得られた発熱ピーク面積より, 含浸 したシラン系表面含浸材の質量を試算する. 試算に当たっ ては，次の仮定を設ける。

(1) ピックで採取した試料には粗骨材は含まず, Table 1より, 水 $\left(169 \mathrm{~kg} / \mathrm{m}^{3}\right)$, セメント $\left(338 \mathrm{~kg} / \mathrm{m}^{3}\right)$, 細骨材 $\left(823 \mathrm{~kg} / \mathrm{m}^{3}\right)$ のみとする.

(2) このうち，細骨材は示差熱分析に影響しないもの とする(コンクリート単体では発熱ピークが現れないこ とからも, 実験 2 と同じモルタル分のみを考える).

(3) Fig. 5 より, 含浸深さは表面から $5 \mathrm{~mm}$ までとし, この間の平均発熱ピーク面積は, $248 \mu \mathrm{V} \cdot \mathrm{s} / \mathrm{mg}$ とする.

細骨材を含んだモルタル分の平均発熱ピーク面積 $248 \mu \mathrm{V} \cdot \mathrm{s} / \mathrm{mg}$ を細骨材を含まないセメントペースト分の 平均発熱ピーク面積に換算すると, $651 \mu \mathrm{V} \cdot \mathrm{s} / \mathrm{mg}$ とな り, これに対応する質量比は式 (1)より 0.0752 である.

一方, 表面から $5 \mathrm{~mm}$ までのセメントペースト分の質 量は,

$$
(169+338) \times 0.005=2.54 \mathrm{~kg} / \mathrm{m}^{2}
$$

である、表面から $5 \mathrm{~mm}$ までに含浸したシラン系表面含 浸材の質量を $\mathrm{s}$ とすると,

$$
0.0752=\frac{\mathrm{s}}{2.54+\mathrm{s}}
$$

となり ,

$$
\mathrm{s}=0.206 \mathrm{~kg} / \mathrm{m}^{2} \text { を得る. }
$$

実験 1 で用いた供試体に適用したシラン系表面含浸材 の使用量は $0.12 \mathrm{~kg} / \mathrm{m}^{2} \times 2$ 層 $=0.24 \mathrm{~kg} / \mathrm{m}^{2}$ であり, 今回 求めた含浸量はその $86 \%$ にあたる。 また，仮定（1）で, 採取した試料を骨材を含まないセメントペースト分のみ と仮定した場合は，同様の計算により $30 \%$ となる.

示差熱分析結果から求めた含浸量が実際の使用量より も小さく算定された理由としては, 実験 1 ではコンクリー 卜，実験 2 ではセメントペーストと基材に違いがあるこ と, 実験 1 の供試体作成が 10 年以上前であり同一メー カーの材料を使用してはいるが実験 2 で使用した材料と
完全に同一でない可能性があること等が考えられる，今 後は, セメントペースト供試体だけでなく, 新たにシラ ン系表面含浸骫を含浸させた供試体から試料を採取して 示差熱分析を行うなど，さらなる検討が必要であると考 えられる。

また，具体的にどのような物質の燃焼によって発熱が 生じているかについても検討が必要である。さらに，七 メントと反応できなかった余剩シランの燃焼によると考 えられる低温側の発熱ピークが生じた質量比 $1: 0.5$ と $1: 1$ のケースでは,

（1） 余剩シランが発生してもなお，高温側の発熱ピー ク面積は上限值を示さず，質量比が高い方がさらに大き くなる.

（2）余剩シランの燃焼によると考えられる低温側の発 熱ピーク面積が質量比の增加とは逆に減少するなどの点 についても，さらに実験・考察を深める必要がある。し かし，低温側の発熱ピーク面積は高温側のそれと比べて 相対的に小さく，また，低温，高温の合計值として発熱 ピーク面積をみると Fig. 14 に示すように, 質量比との 間に良好な相関関係があることがわかる。さらに，実際 の構造物においては, 余剩シランが生じる領域は構造物 表面のごく一部に限られると考えられることから，実用 上の問題は大きくないと考えられる.

\section{4 結 論}

本研究で得られた結果を以下に示す。

（1）本研究に用いた表面保護工は，いずれも，15 年 以上にわたり吸水防止性能や内部からの水蒸気透過性能 が維持される等の効果により, 膨張抑制効果を維持した.

（2）シラン系表面含浸材は塗膜層を除去しても, コン クリート表面に含浸したシランの吸水防止性能, 内部か らの水蒸気透過性能により, 実用上十分な膨張抑制効果 を維持した。ただし，シランの含浸が十分でない場合に は，膨張を抑制できない。

（3）任意の深さから採取した試料について，差動型示 差熱天秤 (TG-DTA) を用いた示差熱分析を行い，320 $370^{\circ} \mathrm{C}$ 付近の発熱ピークの有無を確認することにより, シ ラン系表面含浸材の含浸深さを確認することができる.

（4）供試体，シラン系表面含浸材等，本検討に用い た材料打よび実験条件の範囲内では，膨張抑制に必要な 発熱ピーク面積は $160 \sim 300 \mu \mathrm{V} \cdot \mathrm{s} / \mathrm{mg}$ 程度である.

（5）実用域においては，シラン系表面含浸材の含浸量 と発熱ピーク面積との間に明確な相関関係が認められる ことから，あらかじめ質量比のわかった試料の発熱ピー ク面積と比較することにより, シランの含有量を定量的 に算出することが可能である.

\section{参 考 文 献}

1) Japan Society of Civil engineers, "Standard specifications for concrete structures-2001, “Maintenance””, p.146 (2001).

2 ) Hanshin Express-way Public Corporation and The society of Materials Science, Japan, "Konkurihto kouzoubutsu no hyoumen hogokou binran (an) - dou kaisetsu”, pp.20-30 (1989). 